\title{
THE CORRELATION BETWEEN READING HABIT AND TRANSLATING ABILITY FROM INDONESIA INTO ENGLISH
}

\author{
Hendriani Lesmana \\ IKIP Siliwangi \\ Hendrianilesmana5@gmail.com
}

\begin{abstract}
Languange is important for all human beings in the world, we can communicate with each other from around the world..The main objective of this research entilted "The Correlation between Reading Habit and Translating Abiliy " is to know whether there is correlation between reading habit and translating ability at the eleventh grade student senior high school This research used quantitative method. The sample in this research were 30 students of class eleventh grade senior high school. The instrument used questionnaire about reading habit and translating tests, then they are calculated by using Statistical Package for the Social Sciences (SPSS). With no significant level robs $=0.119$, the result of the test shows that there is negative correlation between reading habit and translating ability with correlation value $r$ is 0.533 . It can be concluded that there is a no significant relationship between reading habit and translating ability of the eleventh grade students of senior high school with low level correlation. This means that reading habits no effect for translating ability.
\end{abstract}

Keywords: Correlation, Reading Habit, Translating Ability

\section{INTRODUCTION}

Languange is important for all human beings in the world, we can communicate with each other from around the world. Talking about learning foreign langauge, it has four skills that have to be mastered by the learners. Those are listening, speaking, reading and writing.

In learning new language, reading is an essential aspect because through reading, people can get new vocabularies and it also can add people some knowledge in transfering source language to the target language. (michael owusu, 2014) stated that reading is an essential tool for knowledge transfer and the habit of reading is an acedemic activity that increases skills in reading strategies.

To know about world its environment, a child help a new vocabularies through reading books, newspaper other magazine. Reading habits is also important for quality skill every people. Students are able to develop their potential and if they are in the habit of reading according to Owusu-Achew(2014) reading habit is an essential and important aspect for creating a literate society in this world.

Therefore reading habit very importance for everyone (adeyinka tella, 2007) .reading is important for everybody in order to cope with new knowledge in a changing world - that of the technological age. The ability to read the depent on self education and how long learning. Books impart knowledge to the reader, draw out and foster qualities such as imagination and self- 
understanding, and contribute to the child's mental growth by stimulating the senses of touch, sight and hearing the three main channels by which people learn (adeyinka tella, 2007).

Stated (michael owusu, 2014) Reading habit is best formed at a young impressionable age in school, but once formed it can last one's life time.

Reading is an intelectual action and practice these from chidhood. Reading has a positive influence on academic perfomance (Iftanti, n.d.)The enviroment for habit of reading develop ability add new imagination to written description but we need process to achievement from habit of reading.

Translated can be develop ability for students and new knowlegde especially English. This research of study the writter will examine reading habit and translating ability to know their habit of reading, entitled the correlation is reading habit and translating ability from Indonesia into English is there correlation or not between two variables. Reading In learning new language.

A good reading is important for the development of a person since it is particulary education and important to growth of a person. (adeyinka tella, 2007) asserted that the ability to read is at the heart of self-education and lifelong learning and that is an art capable of transforming life and society. As stated by (Rizqiya, 2013) Reading can be used transfering language in education although reading is not a subject the curriculum. In reading, readers' knowledge is transferred by the writers.

(Hesham suleiman alyousef, 2006) states that any reading component of an English language course may include a set of learning goals for the ability to read a wide range of texts in English.this is long-range goal most teachers seek to develop through independent readers outside EFL/ESL classroom.

1. Building a knowledge of language which will facilitate reading ability.

2. Building schematic knowledge.

3. The ability to adapt the reading style according to reading purpose (i.e.skimming, scanning).

4. Developing an awareness of structure of written texts in English.

5. Taking a critical sentence to the contents of the texts

(Rizqiya, 2013) states that Reading is an active process related to problem solving. Purposes of reading any pointed up seven purposes the reading as stated (Rizqiya, 2013):To search for simple information, to skim quickly, to learn from the texts, to integrate information, to write, to critique texts, to comprehend the text generally. This reading activity is likely more to emphasize to accuracy activity involving reading for detail. It is called scanning.

The process of scanning takes a more prominent role than skimming in this type of reading. Readers is trying to catch the information in a short time, examples: reading instructional Extensive reading involves longer text as a whole, which requires the ability to understand the component part and their contribution the overall meaning, usually for ones' own pleasure. This is a fluency activity, mainly involving understanding. Example: reading novel, newspaper and article.

Reading Habit must bepracticed regularly over and over until it becomes the second nature for the learners. Hence,repetition of reading activities plays a major role for the establishment of 
reading habits (Iftanti, n.d.).A good reading habitrelated to the behaviors of reading different kinds of reading materials which are regularly, permanently and intentionally conducted so it becomes a partof the students' daily activities.

To have an ability to cope with the demand in translating and to develop reading habits inEnglish is significant forstudents because they are engaged much in reading English literatureto achieve their academic success. Academic achievement means how much knowledge the individual has acquired from the school (michael owusu, 2014).

(Iftanti, n.d.) claimed that there are some external factors that can influence reading habit of an individual such as environment, education, social background, and facilities.In addition, the success of reading practices is influenced by some factors such as students'home environment including parental influence, parental involvement, environmental influence,social class, and accessibility to reading materials. Continuation of students' languageexperience is a home language learning which they bring into the classroom. How language mastery developed in their daily life.In the developing knowledge of society, reading plays a significant role in gaininginformation which prepares a person to face the various challenges of modern times.

Reading is undoubtedly important in education in term of the intellectual growth of a person. Tella and Akande (2007) coined that the ability to readers an art capable of transforming life and society. They also added that the ability to read is at the heart of self-education and lifelong learning.

\section{METHOD}

Kaswan and Suprijadi (2016) described research design as the arrangement of conditions for collecting and analysing data in a manner that aims to combine relevance to the purpose. The data can be interested exhibit type of the correaltion.In this study the writer to compare two variables, those are reading habit and translating ability. Those variables score gained by questionnaire and pretest.

The writer want to know is any correlation between two variables. Reseach is an academic activity and as such the term should be used in a technical sense (Kathori, 2004). There are four kinds of method that can be applied in quantitative research design, those are 1) experimental method, 2) correlational method, 3) causal-comparative method, and 4) survey method. In this research, correlational method is applied for collecting the data Cresswell (2012). Correlational refers to " research that involves collecting data in order to determine the degree to which a relationship exists between two or more variables" Kaswan and Suprijadi (2016). Research Method In this study the writer use quantitative data to acquire.

As Kaswan and Suprijadi (2016) said that quantitative research is a deductive theory-based research process that focuses primarily on testing theories and specific research hypotheses that consider finding differences and relationships using numeric data and statistical methods to make specific conclusion about phenomen.

Population and Sample,Population is the whole research object. The population of this study was the whole students eleventh grade of SMA Darul Falah Cihampelas which consists of 240 students.Sample is part of the total number and characteristic belong to population Arikunto (2013). This study was conducted in XI IPS 4. The sample of this study was 30 students. 
There were 2 kinds of instruments used in the study an questionnaire and test was used to observe, document and interpert the process of learning habit of reading and translating ability. According to Tavokali (2012) in Kaswan and Suprijadi (2016) Instrument is any device which is used to collect data. Instrument can be presented in written, audio, or visual format. The writer used a questionnaire and test as the research instrument.Based on the problem faced by students, and action would be conducted. The data collection technique will be based on the one group questionnaire and pretest

\section{RESULTS AND DISCUSSION}

\section{Results}

In this part, the writer discussed the result of the research. It includes the result of the questinnaire that was given to the sample which consisted of 12 questions with 2-point likerttype True and False get point each. The maximum score is 24 and the minimum score is 10. The questionnaire was given on 27 february 2018 to the eleventh grade students of social four in SMA Darul Falah Cihampelas in academic year 20172018. The result of reading habit can be seen in table 1 .

Table 1. Reading habit Scores

\begin{tabular}{|c|c|c|}
\hline No & Name & Reading Habit Scores \\
\hline 1 & Students 1 & 14 \\
\hline 2 & Students 2 & 10 \\
\hline 3 & Students 3 & 18 \\
\hline 4 & Students 4 & 14 \\
\hline 5 & Students 5 & 16 \\
\hline 6 & Students 6 & 14 \\
\hline 7 & Students 7 & 16 \\
\hline 8 & Students 8 & 12 \\
\hline 9 & Students 9 & 18 \\
\hline 10 & Students 10 & 18 \\
\hline 11 & Students 11 & 20 \\
\hline 12 & Students 12 & 18 \\
\hline 13 & Students 13 & 22 \\
\hline 14 & Students 14 & 18 \\
\hline 15 & Students 15 & 12 \\
\hline 16 & Students 16 & 16 \\
\hline 17 & Students 17 & 10 \\
\hline 18 & Students 18 & 18 \\
\hline 19 & Students 19 & 12 \\
\hline 20 & Students 20 & 16 \\
\hline 21 & Students 21 & 18 \\
\hline 22 & Students 22 & 14 \\
\hline 23 & Students 23 & 14 \\
\hline 24 & Students 24 & 14 \\
\hline 25 & Students 25 & 18 \\
\hline 26 & Students 26 & 10 \\
\hline
\end{tabular}




\begin{tabular}{llc}
\hline 27 & Students 27 & 18 \\
\hline 28 & Students 28 & 10 \\
\hline 29 & Students 29 & 14 \\
\hline 30 & Students 30 & 20 \\
\hline Total & & 462 \\
\hline
\end{tabular}

from the table above showed that the score maximum score is 22 and minimum score is 10. Students get score maximum is only one of students and student get minimum score is four of students. It means most of students have some a good reading habit in learning English.

\section{Translating Ability}

In this part, the writer disscused the result of the research, it includes test translating that was given to the sample which narrative test and translating from Indonesia into English. The maximum score is 100 and the minimum score is 10,

The test was given on 13 march 2018 to the eleventh grade students of social four in SMA Darul Falah Cihampelas in academic year 20172018. The result of translating ability can be seen in table 2

Table 2. Translating ability Scores

\begin{tabular}{|c|c|c|}
\hline No & Name & $\begin{array}{c}\text { Translating ability } \\
\text { Scores }\end{array}$ \\
\hline 1 & Students 1 & 70 \\
\hline 2 & Students 2 & 90 \\
\hline 3 & Students 3 & 80 \\
\hline 4 & Students 4 & 80 \\
\hline 5 & Students 5 & 90 \\
\hline 6 & Students 6 & 70 \\
\hline 7 & Students 7 & 80 \\
\hline 8 & Students 8 & 70 \\
\hline 9 & Students 9 & 70 \\
\hline 10 & Students 10 & 60 \\
\hline 11 & Students 11 & 60 \\
\hline 12 & Students 12 & 90 \\
\hline 13 & Students 13 & 70 \\
\hline 14 & Students 14 & 80 \\
\hline 15 & Students 15 & 70 \\
\hline 16 & Students 16 & 70 \\
\hline 17 & Students 17 & 80 \\
\hline 18 & Students 18 & 80 \\
\hline 19 & Students 19 & 60 \\
\hline 20 & Students 20 & 70 \\
\hline 21 & Students 21 & 70 \\
\hline 22 & Students 22 & 70 \\
\hline
\end{tabular}




\begin{tabular}{lll}
\hline 23 & Students 23 & 70 \\
\hline 24 & Students 24 & 70 \\
\hline 25 & Students 25 & 90 \\
\hline 26 & Students 26 & 80 \\
\hline 27 & Students 27 & 80 \\
\hline 28 & Students 28 & 70 \\
\hline 29 & Students 29 & 80 \\
\hline 30 & Students 30 & 70 \\
\hline Total & & 2.110 \\
\hline
\end{tabular}

Based on the result of Translating ability score above it can be seen that the maximum score of translating ability test is 90 and the minimum score is 60 . The students get maximum score is four students and the students get minimum score is three students. it means the student can provide a literal, word-for-word translation that captures the main idea and details of the text.

\section{Discussion}

The research purpose to knew correlation between reading habit and translating ability from Indornesia into English, the writer found a some problem in habit of reading and translating ability the writer conculded eleventh grade students of SMADarul Falah Cihampelas. Based on the results of the research findings, the writer analyzed that the correlation is negative.

Negative correlation means that the reading habit and translating ability from Indonesia into English get low score because they have lower score in reading habit. From the calculation, the score of $\mathrm{r}_{\mathrm{obs}}$ which is 0.119 is including in the criteria of the power of two variables relationship categorizes very low correlation. It means that there is a negligable correlation between reading habit and translating ability from Indonesia into English. The writer analyzed as well that there is a significant correlation variables due to the score of significant is 0.533 (2-tailed).

Finally, the writer concluded that the alternative hypothesis of the research was acceptted since the result of the research findings showed that of the two variables, reading habit and translating ability, there were negative correlation, low correlation, and no significant correlation.

\section{CONCLUSION}

Based on the research which have been discussed in the previous chapter, the writer concluded as follow:

The students at XI IPS 4 in SMA Darul Falah Cihampelas Cililin consist of 36 students but in this research the writer took 30 students because at the time writer give the test, the students who actively follow both of test amounted to 30 students. The result of not normality test based on Kolmogorov-Smirnov test shows that the reading habit no significance value is 0.02 and translating ability significance is 0.00 it means that both of variables are not normal. The significance value is 0.119 , it is higher than 0.05 and it means that alternative hypothesis (Ha) "there is a positive correlation between reading habit and translating ability" is rejected.

The correlation coefficient between two variables shows -0.119 . In another words, there is a negative correlation between reading habit and translating ability. It means that level of reading 
habit has no effect on translating ability. The correlation coefficient value is -0.119 . Based on Mukaka the criteria .00 to .30 (.00 to -30) are considered negligible correlation. In other words, correlation of two variables is very weak and can be ignored.

\section{ACKNOWLEDGMENTS}

Praise to Allah who has given us knowledge healthy and opportunity. The accomplishment of this research paper is made possibly because of Allah's help and mercy. Shalawat and salam are presented to our prophet Muhammad SAW, who has brought people from the darkness into brightness age of knowledge.

\section{REFERENCES}

Owusu-Achew, M. (2014). Reading Habits Among Students and its Effect on Academic Performance. Library Philosophy and Practice(e-journal), 3.

Tella, A. (2007). Children Reading Habits and Availability of Books in Bootswana Primary Schools. The Reading Matrix , 5.

Rizqiya San Rissa (2013). The Use of Mind Mapping in Teaching Reading Comprehension.ELTIN journal , vol 1

Kaswan and Suprijadi Dasep (2016). Research In English Language Education. Bandung: Putra Pratiksi 